\title{
Stephen Carney*
}

\section{Reform of Higher Education and the Return of 'Heroic' Leadership: The Case of Denmark ${ }^{* *}$}

Denmark is experiencing a comprehensive package of educational reform aimed at enabling that country to recalibrate itself to the demands of the so-called 'global knowledge economy'. In relation to the higher education sector, a new system of university governance is being implemented where boards are appointed (ultimately) by the State and comprised of a majority of members external to the institution. To further shape (if not direct) the work of universities, the new University Law requires that institutions prepare a 'development contract' with the Ministry, and that this is used as a framework within which universities direct their activities. To facilitate this process a new conception of leadership is invoked. Whilst university leaders ('rektors' in the Danish context) were previously elected by the academic staff of the institution, the new arrangements require that they be appointed by the board which looks to the rector to 'run' the institution and fulfil the demands of the development contract on their behalf.

The study reported here utilises ethnographic method to explore such issues at a time of unprecedented change in Denmark. Notions of the leader as 'hero' - common in contemporary universities despite the general shift in the business world to notions of transformational and distributed leadership - appear not only difficult to eradicate but positively emboldened by the current reform movement. The paper explores different understandings of leadership, both in the literature and 'in action' via the perspectives of university leaders and decision-makers in the Danish case, before considering whether the current reforms make necessary such models of control and if the scope of action of such leaders is seriously curtailed by contemporary education policy.

Key words: Leadership, University Reform, Education Policy

* Dr. Stephen Carney, Department of Psychology and Educational Studies, Roskilde University, DK - 4000 Roskilde, Denmark, Phone: + 45 46742414, Fax: + 45 46743070, e-mail: carney@ruc.dk.

** Article received: October 19, 2006

Revised version accepted after double blind review: March 10, 2007. 


\section{Introduction}

'...we appear to be programmed towards seeking out single causes or sources to order complexity...observing a flock of birds in flight makes us assume straight away that the bird out in front is the leader who sets the flight path...yet no such thing happens.' (Lakomski 2005: 16)

The Danish University Law of 2003 (MVTI 2003) represents both a continuation of a process of change in Danish higher education as well as a clear departure from existing practice and tradition. On the one hand, the reform continues a process of opening up universities to their constituencies, streamlining management and funding processes and improving the connections between education and employment. In other respects, though, the Law represents a violent departure from Danish custom; imposing from above new hierarchies and power relations and removing from universities themselves the obligation of self-governance from amongst the faculty (see Krejsler 2006 for an elaborated discussion of the changing discursive space of Danish universities).

The overall policy script for these changes is the partially understood challenge of the so-called 'knowledge economy'. Universities are being identified, along with the formal schooling system, as key contributors to Denmark's future economic prospects. Educational programmes are being shaped to better meet the needs of the labour market and research provision is presently being rationalised to create 'economies of scale' that will enable fewer but larger Danish institutions to compete 'globally'. Research is also under pressure to become more commercially-oriented both in terms of formal agreements to share and transfer knowledge, and more generally in terms of disseminating findings to the public. This latter demand will play an increasingly significant role in researchers' own administration of what counts as 'relevant' and thus legitimate.

The 2003 Law is a central element in this overall policy framework. Here, university governance and management have been subject to a radical overhaul. Decisionmaking processes have been reformed via the establishment of new boards comprising a majority of members from beyond the university itself. This body is now responsible directly to the Ministry for the successful operation of the institution, not least in terms of over-viewing the university's budget and providing a framework for institutional management. Its initial work included the establishment of a charter and bylaws, the preparation of a development contract ${ }^{1}$ with the Ministry, and the appointment of a rector to act as the institution's 'chief executive'. Similarly, deans and heads of department/ institute, once elected by the permanent academic staff of subject group-

1 Whilst development contracts were first introduced in the Danish case in the 1990's, the current requirements are for a very specific and detailed statement of the University's overall goal and vision, its specific plans and programmes for the coming three-year period and an elaborated set of measurable outcomes. These documents are written by each university but with detailed input from the Ministry. In many cases, development contracts have been the subject of protracted negotiations between each university and the Ministry as the Government seeks to secure agreement on concrete and thus assessable outcomes. 
ings, are now appointed by the rector, who is vested with the power to set salary and 'performance' packages for 'line managers'. These instruments and actors are viewed by policy makers as part of a coherent system aimed at streamlining universities and making them more effective in the face of increased economic pressures from within the Country, and ready to meet the new international competitive knowledge 'markets' in which they now find themselves.

Changes at the institutional level have been rapid and deep, bringing to realisation many of the fears voiced by critics of the new Law. Board processes are clearly different from earlier managerial regimes and have led to claims that decision-making in universities is effectively disconnected from the realities and concerns of researchers, teachers and students (e.g. Carney 2006). Rectors - once elected politicians required to manage and sustain their constituencies - are emboldened by a new discourse of competitiveness and crisis, and can now be seen only in their managerial 'bunkers' or on route to meetings flanked by aides and 'court attendants'. New accountability regimes (between university and ministry; between rector and board; between academic worker and department/ institute leader; and between academic worker and student) are breaking down collective organisational forms as well as the sense of shared purpose that has shaped much of Danish higher education culture.

The alignment of new decision-making organs, executive leadership and accountability systems are changing radically how we can and might engage with the university at the present time. The adoption of what Ball (1995) has called 'unreflexive' and 'utilitarian' languages from the economic sphere, the imposition of new knowledge regimes based on the primacy of techno/rational planning, and the construction of new forms of power manifest as executive leadership bound contractually to unelected boards and intrusive ministries, represent nothing less than a new discursive regime in Danish higher education.

The paper explores these issues by providing different theoretical understandings of leadership as well as insights from interviews with board members and senior 'managers' at a cross-section of three Danish universities. With this base, ethnographic field work has enabled me to describe the 'space' being made by these actors in terms of the actual manifestations of leadership in the Danish university context. Finally, I consider how we might work with the signifier of 'leadership' in the future. Two broad themes are explored.

First, the education sector in Denmark, and especially universities, is being constructed by Government as needing radical and rapid change. Leadership is conceptualised as a crucial variable in the reform equation. Here, the 'heroic' individual is being elevated to a pre-eminent position, given responsibility for affecting change and, importantly, being held accountable for the 'product' generated by 'his' institution (women are missing from the highest level of management in universities).

Second, and related, it is argued that the elevation of a key individual to 'transform' the organisation is a theoretical resource developed with the industrial sector in mind. It is debatable that such individuals can mediate the ideological differences inherent within educational institutions, or motivate staff to change fundamental attitudes about how and what to learn. In general, it is debatable that executive leadership 
is even relevant in highly complex knowledge-creating organisations such as universities where academic workers define themselves in terms of autonomy. Nevertheless we are certainly experiencing something by that label in Denmark. I argue, however, that what we are witnessing in Danish university reform, and conveniently critiqued as top-down leadership, is better understood in terms of new constellations of power and control which, by other means, continue historic processes of domination in education.

\section{Theorising about leadership}

Theories of leadership are many, exist across academic disciplines and have in common a desire to better understand social phenomena, in most cases in order to improve it. Selecting a theoretical standpoint in a field characterised by such diversity, contradiction and normativity is contentious at best and counterproductive at worst. To provide meaning to my empirical observations, however, I suggest three broad ways to present the mass of work aimed at conceptualising leadership.

First, I return to James MacGregor Burns' (1978) influential text, Leadership, in large part because of his own attempt to bring together what he saw as two powerful tendencies in the literature. Here, the unhelpful split between the literatures on 'leadership' and 'followership' is exposed in terms of work on leadership that focuses on the 'heroic or demonic figures' of history (trait theories rest comfortably here) and work on followership which tends to focus exclusively on what he calls 'the people':

The leadership approach tends often unconsciously to be elitist; it projects heroic figures against the shadowy background of drab, powerless masses. The followership approach tends to be populistic or anti-elitist in ideology; it perceives the masses, even in democratic societies, as linked with small, overlapping circles of conservative politicians, military officers, hierocrats, and businessmen. (Burns 1978: 3)

By focusing on the need to locate leadership research in the 'structure and processes of human development and political action' (ibid: 8), Burns attempts to unite the two literatures within a theory, if not an ideology, of political action and conflict:

...leadership is nothing if not linked to collective purpose...that political leadership depends on a long chain of biological and social processes, of interaction with structures of political opportunity and closures, of interplay between the calls of moral principal and the recognized necessities of power; that in placing these concepts of political leadership centrally into a theory of historical causation, we will reaffirm the possibilities of human volition and of common standards of justice in the conduct of peoples' affairs. (Burns 1978: 4)

In conceptualising actual leadership practice, Burns focuses upon two 'basic' types: leadership as transaction and leadership as transformation. Leadership as transaction rests on the notion of exchange for mutual benefit and is grounded firmly in a politics of pragmatic action. For Burns this approach to leading people continues to dominate action in organisations. Leadership as transformation, however, is ultimately a moral project aimed at reaching the higher inner and authentic desires of followers. Rather than the leader as 'born' (i.e. trait theories), or commissioned/ mandated to trade and exchange followership for favours (i.e. transactional approaches), transformational leadership is held up as a rarely practised but necessary way to change the world. 
The extent to which transformational approaches have been adopted since Burns' book can be debated. One impediment to deep change has been what he calls the 'power' of heroic models of leadership. Citing Weber's notion of authority 'types', Burns suggests that as societies move from the charismatic, the ration-legal and the traditional, so to do leadership approaches. 'Miraculous' leadership (for example by religious figures or revolutionaries) becomes surpassed by a rationalisation process wherein charisma becomes bureaucratised and regulated. This is followed by a period of tradition in which an accepted approach to leadership is legitimated by usage, precedent and custom (ibid: 243). However, this transition is cyclical, in part because traditionalisation responds poorly to external threats and strains. It is in such times that heroic leadership returns. For Burns, this is understood as a:

... belief in leaders because of their personage alone, aside from their tested capacities, experience, or stand on issues; faith in the leaders' capacity to overcome obstacles and crises; readinesss to grant to leaders the powers to handle crises; mass support for such leaders expressed directly - through votes, applause, letters, shaking hands - rather than through intermediaries or institutions. Heroic leadership is not simply a quality or entity possessed by someone; it is a type of relationship between leader and led. (Burns 1978: 244)

It is important here to note that heroic leadership is a category that emerges from within a system with the consent and support of that system. It is the clear signal from the system itself that change is required and that faith is to be placed in some great individual who might deliver salvation.

A second approach to the field of leadership research is to group together the work since Burns' book in terms of research that has recognised and legitimised the issues raised there - especially the project of bringing about social change - but which has found or suggested other paths to the realisation of improved workplaces. Some of this attempts further theoretical elaborations on the transaction/ transformation distinction where the 'traits' of the chosen leader remain crucial (e.g. Bass 1985; Bass/Avolio 1994). Others focus on his notion of morality or ethics, and this is embodied in contemporary work via notions such as 'democratic leadership' (e.g. Moos 2006). Some take the ideology of individual follower-empowerment to its logical end with the notions of 'hospitable leadership' (e.g. Green 1994) and, even, 'servant' leadership (e.g. Greenleaf 1998)!

These positions still fill the spaces of research on educational leadership in universities. For example, in Baldridge's groundbreaking study of organisational decisionmaking (Baldridge 1971) and Cohen and March's (1974) work on American university presidents, the focus was on understanding contexts and political cultures in education in order to shape leadership profiles and styles. More recently, those attracted to the idea of the 'triple helix' (e.g. an attempt to reconceptualise university, industry, and government relations, often without due recourse to theories of the state, power, identity etc) view leadership in universities as concerned with releasing creative forces, protecting workers from excessive external demands and enabling the types of flexibility and fluidity that correspond to late modern society (e.g. Etzkowitz 2002). Another strand, 'self leadership', recognises the primacy of leadership as an organising concept, albeit by denying its essence. Here, we are told that 'leadership' (by definition a relation between 'leader' and 'follower') is driven down into the 'micro' practices (and 
subjectivity?) of each autonomous worker who carries out 'self-guided leadership' within the overall framework of (low) hierarchy management (e.g. Ernø-Kjølhede et. al. 2000). Irrespective of their precise perspective, all of these cases view leadership as a legitimate and urgent category to be attended to.

A Third approach, and an alternative to these positions, rejects leadership as an independent 'object'. Gabriele Lakomski and her colleague Colin Evers have attempted to develop a research programme aimed at questioning what they see as the 'folk-psychological and functionalist' foundation of leadership studies. Historically, leadership research has had only the loosest of connections to the 'parent' discipline of organisational theory. Further, its capture by the human relations movement with its concern for effectiveness and improvement have made the concept of leadership impervious to critique by the wealth of empirical work that makes clear that, with the exception of extremes (i.e. 'good' and 'bad' practices) it is not impossible to generalise about social settings sufficiently to attribute workplace outcomes to the 'variable' of leadership. In large part, this is a consequence of what Lakomski refers to as the 'hypothetico-deductive' manner in which leadership is studied. In short, 'leadership' is recognised as a pre-existing category, and studies are then designed to collect individualised claims about social action which support the concept, leading to processes of re-theorising (Lakomski 1999).

This epistemological paradigm has been largely rejected in the social sciences but lives on in studies of leadership, even though the findings from these empirical studies show little consistence or causality between 'leadership' and context/ practice. Rather than contribute to this project, Lakomski and Evers have attempted to explore organisational life from the 'bottom-up' in order to explain how, and under what conditions people in complex systems organise themselves. Their conclusion; that 'law-like statements' about leadership as 'postulated by empiricist theories of leadership' cannot be made, leads to a focus on organisational learning and the construction of 'web-like organisational structures which maximise the local production of knowledge and facilitate the correction of error through feedback mechanisms' (Lakomski 1999: 37).

One could argue that this alternative programme nevertheless falls into many of the same epistemological traps as leadership research. As importantly, it appears like much work on the so-called 'learning organisation' to under-theorise power. Nevertheless, it forces uncomfortable questions on any one concerned with understanding, if not improving, life in organisations.

This is a wide-ranging summary that can be taken further in different ways. For our purposes, however, a number of conclusions seem most relevant:

- Danish education policy (both in the school system and university) places central importance on the role of ordained and accountable leadership. It is the preeminent variable in contemporary educational reform.

- Research into the phenomena of leadership suggests that we have struggled to rid ourselves of the notion of the 'heroic' individual; a figure that often emerges during the transition from traditional forms of organisation to those marked by flux and crisis. 
- Importantly, however, this heroic individual is a product of a bottom-up process of identifying a 'saviour' into which our hopes, fears and autonomy are placed. By definition, it cannot be a figure imposed upon an unwilling mass.

- In the Danish case, however, policy has been constructed against the backdrop of crisis and the need for radical/ drastic action. With this political space laid out, new leaders have been 'parachuted' in to 'save the day'.

- Not only does this form of 'heroic' leadership suffer from problems of local legitimacy, there is no basis on which to assume, firstly, that 'knowledge workers' in universities assent to such leadership or, second, that it even exists in organisational forms categorised by complexity, interconnectivity and high degrees of autonomy. Current Government policy may very well be a poor response to poorly formulated problem.

\section{Leadership in practice}

The empirical data presented here comes from a sustained period of data collection during 2005/2006. In addition to analysing policy texts and public utterances related to the 2003 Law, interviews and field observations took place in three Danish Universities which, at that time, were negotiating the transition to the new regime ${ }^{2}$. Here, rectors, university directors, senior staff and a selection of board members were interviewed with many of these discussions having as their point of departure my observations of the newly constituted boards in action.

Approximately 25 interviews were conducted, with the focus on the transition process between the former 'university senate' and the new board, members' vision(s) about universities in contemporary society, the role of the board in the daily life of the university, and the particular roles of different subject positions on the boards (i.e. internal and external member roles). A further interest was to explore the relationship(s) between university boards and other internal bodies, especially informal senior management bodies and advisory organs. Here, there was an interest to learn about the ways in which these advisory organs were responding to the new executive decisionmaking structure.

The Law deals with a range of structures and relationships within and across the university, making clear that the rector is its central figure in terms of day-to-day management. Whilst this relationship is circumscribed by the board (i.e. the framework for management is established by the board, and it is the board that has ultimate responsibility for the university's budget and its development contract with the Ministry), the rector has direct power in relation to all university employees and all matters with the exception of real estate. The rector is even charged with power over academic council, and may dissolve this body under 'special circumstances', assuming its tasks personally.

In broad terms: an established or 'traditional' institution containing a wide cross-section of research and teaching interests and viewing itself very much in terms of the Humboldt legacy; a 'reform' university with a commitment to student-focused teaching and interdisciplinary work; and a single-subject institution serving a specific sub-sector of Danish public service, industry and commerce. 
This mandate is wide-reaching and whilst the board is given powers to shape the rector's work, it was interesting that many of those interviewed accepted fully the right of the rector to act as chief executive and establish a new constellation of internal relationships. Taking as given that the university required a new direction, some board members - and especially those from the private sector - provided the images of 'coach' and 'change agent' to describe the new role of the rector. For one external member, this meant supporting staff, motivating them and leading by example. Others took this further and spoke of the need for the rector to be 'visionary'. In the words of another external board member:

...leadership is about being able to create an environment and systems and to communicate...so much is about creating meaning. (External board member)

Whilst some reinforced the right of the board to 'control' and 'guide' the rector's work, others noted that the board was 'dependent' on his 'inputs' and that the future direction of the institution was likely to be 'determined' primarily by the rector's vision and programme. For some, this was explained as being a necessary part of the dynamic between appointed boards and their chief executive. For two of the three board chairpersons interviewed, the issue was simple: the convention in Denmark was that board chairpersons did not 'interfere' in the daily management of the 'business' and that it is the 'rector's institution'. Here, decisions could only be made in response to the proposals put forward by the rector.

These positions, based largely on the experiences that members brought with them from private boards, were complemented by a number of critical voices who suggested that there were few other practical alternatives. Here, a number of external members in particular confessed that they were largely ignorant about the inner workings of the university (one even suggested that she had been invited to join the board because of her generic experiences in 'restructuring' organisations!) and that the board processes, especially the practice of relatively short and infrequent meetings, provided a restricted basis on which to act:

I think they (rector and chairman) work closely and they're in close contact with each other. We only have these board meetings four/five times a year but the chairman is there perhaps once a week so nothing really happens that he does not agree on... sometimes you think 'why does he need a board'? When you don't meet that often then you don't really get to decide on major issues. Many things have to be decided between board meetings because they can't wait for a decision by the board. Once in a while we get an email saying 'we need to do this or that, would you give us your view points on whether you think that's ok?' (External board member)

For this board member, the tight connection between the chairperson and rector highlighted the new dynamic in universities where, rather than manifesting the essence of the university in terms of its staff and students, the board was a 'team', constructed strategically to meet the need for rapid and coordinated change:

... you have somebody (at this university) who has been the rector before and he actually chooses the board chairman to some degree. They go round scouting for people and they choose the board. I mean I'm there because (rector) thought it would be a good idea...so you get the board you more or less want. If you look at boards in maybe ten years' time there will be a different kind of board, that may not reflect to the same extent the rector 
or the directorate's wishes for what they want. So there's a closer connection today than there (has been before), even than there should be. (External board member)

Notwithstanding this diverse range of explanations, it seemed clear that board members, especially those appointed from outside the university, accepted the limitations of their role. One could argue that these limitations were built into the structure of the role, and indeed some referred to the board only as a 'sounding board' and a place for 'dialogue'. Others claimed openly that they lacked the knowledge to intervene deeply. All expressed the view that trust was essential in the new system. In the words of one board chairperson:

... the board, like any other board of a company, of course, has as its primary source of information the person in daily charge, and in the university setting that's the rector ... it is a pretty basic thing that as a board....you have to trust the daily management and trust it to bring forward the important information....the rector is the central link between the institution and the board... (Board chairperson)

In a system based on the need to satisfy accountability demands upward (i.e. the rector is accountable to the board and the board to the minister), it seemed essential that the board took at face value the recommendations and perspectives presented by its 'chief executive officer'. Few board members claimed to have had an active role on campus, although some had previous working histories as academics at the institution. Some even claimed that this would be inappropriate. As a consequence, the vast majority reiterated the view that the most important - indeed the only independent - decision to be taken by the board was the appointment of the rector. As another board chairperson explained:

That's the only real decision where we are on our own in the board. All other things should ideally be prepared by the daily management and then discussed and corrected and changed and so in the board but we should not be the ones bringing the issues up....So the only independent decision and initiative is employing the rector; the managing director in another context. (Board chairperson)

This position is quite likely to be read by academic workers with some degree of frustration, if not anger. In short, it appears that executives brought in from the world of industry and commerce have interpreted the Law in its narrowest possible way and attempted to introduce systems and disciplines that are simply alien and counterproductive. However, another view, expressed by an internal board member with over 20 years experience of elected university governance, pointed to the structural constraints imposed by the new system, and did so by contrasting the new situation with the now disbanded university senate (In Danish: 'konsistorium') model:

If you look at it from my particular position on the Board, I would say that there was a much better process in the former Senate ('konsistorium'). But this concerns something completely different which the Law has overlooked. It's not the (university's) fault, it's the fault of the way the Law has constructed university organs. If you step back into the past you would see representatives on the institute council, in academic advisory groups and on the Senate. So you could easily see that there were people like me at many levels. And because we had a very tight network there was a large forum for discussion when one went about making strategies. One could follow this process from bottom to top. Now, if I think about my position on the Board where I am the only technical-administrative rep- 
resentative (from within the University) there is a long way to the bottom and I cannot follow the process that takes place in between. (Internal board member)

This structural constraint created a challenge for leaders at the university, but one which was being missed or, worse, manipulated.

In all three universities there was a commitment to involve staff and students in university decision-making processes. This took a number of organisational forms. Academic council, with its advisory role, remains the most explicit and open central forum at most Danish university campuses. However, whilst the leadership at one of the three case study institutions claimed to work towards maintaining a central role for academic council, the reality appeared quite different with fewer and fewer strategic issues being generated from within its broad base. Here, senior members of academic council were worried that the board, the rector and his informal senior management group, were using academic council primarily as a 'rubber stamp' to legitimise decisions being made by the managerial elite. The example of the university's strategic plan and development contract were cited, with the reflection that these could only be properly viewed as 'owned by senior management'. At another case study institution, the newly appointed leader marked his first encounter with academic council by insisting that student-observers be excluded from the meetings, citing 'the new context in which we must work'.

Whilst papers, minutes and supplementary materials were 'available' at all three institutions, it was common during the field work phase of the study for these materials be less and less accessible. Board papers at one university were only available from the rector's office. At another, they tended to appear on the internet on the day of the meeting or, in some cases, only after prompting by the researcher! Famously, one of Denmark's leading technically-oriented universities (and not one of the case study institutions) called a board meeting in the Spring of 2006 with an agenda of 11 items, four of which were 'closed' to observers, staff and students; an additional 4 of which were largely trivial. All strategic business of the University was now disconnected from the every day life of its members.

Perhaps the most insightful case is that of the rise of senior leadership or management groups (In Danish: 'direktion'). Here, an increasing centralisation of power and influence is taking place under the control of the rector and with little or no clear relation either upwards to the university's board, or downwards to its various consultative bodies. As one internal board member observed:

The leadership team ('direktion') has daily responsibility for the University's economy. They appoint certain leaders...in reality it is the rector that appoints the institute leaders. He ensures that things function the way he wants them. As such, he convenes them occasionally in order to pass on information about how things should proceed. One knows that it is the leadership team that makes the decisions but this group consists only of the rector, the two deputies and the chief administrative officer (In Danish: 'universitetsdirektør'). There is not much democracy in that! (Internal board member)

And, from the same board member:

I think that if an organ like the senior leadership group (direktion) opened its meetings up, there would be a much greater risk that observers would attend than is the case with 
the board. But there has never been a discussion of whether or not their meetings should be open or closed! (Internal board member)

For this respondent, the discussion about 'democracy' in universities had been 'sidetracked' by the ongoing focus on the role of the board in relation to the earlier elected university senate ('konsistorium'). By definition and structure, the board has a strategic and supervisory role in supporting the rector and in representing the university in its external relations with the ministry. The host of daily decisions to be made in universities that were all under-going rapid change were now being made in the corridors around the office of the rector in the name of the university and its members but by no means with their active or knowing involvement. This organ is not a body enshrined in the legislation and thus to be endured or accepted. Rather, it can be viewed as the best attempt by the 'chief executive' to combine fast and efficient control of strategic and operational decision-making with some degree of broader (albeit narrow and elite) staff involvement. The lack of critique of these local constructions was, according to many respondents, a more telling sign of the new power relations in Danish higher education.

\section{Conclusion}

Even though the University Law of 2003 enshrines dialogue via a structure of advisory organs, it appears that these are being hollowed out and replaced by other more effective, non-transparent and executive bodies. How can this be understood?

First, I suggest that Danish universities are manifesting the contradictions typical of complex capitalism (e.g. Ball 1998). In balancing its role as a provider of public goods and services with its need to act as a private and competitive firm, universities are reorganising themselves in quite contradictory ways. On the one hand, executives are taking charge of decision-making processes, often with little more than perfunctory regard for the multiple viewpoints and perspectives of staff. At the same time, though, these very same 'leaders' are asking for unprecedented levels of loyalty and commitment to the 'group project' of institutional survival and regeneration. Informal and opaque senior leadership groups such as 'direktion' are perhaps best understood as one manifestation of these competing forces: elitism in the service of collectivity. One could understand university boards in the same way.

Second, and related, the competitive pressures facing Danish universities, to say nothing of the raft of incoherent and constant policy suggestions (recommendations fit poorly with the spirit of new public management!) mean that appointed leaders must negotiate, rapidly and under pressure, substantial strategic matters affecting the institution's competitive position but also with due acknowledgement of its collegial history and 'soul'. New internal steering instruments such as 'direktion' are perhaps the best solution to these pressures. To a large degree, the policy context at present may be giving university leaders little choice but to mediate between external demands and local history in such violent and provocative ways.

Thirdly, though, research on the return of heroic models of leadership appears lacking in one arena that may provide deep insight into the current state of university decision-making in Denmark. Whilst a number of sub-fields in education have been enriched by studies of identity and subjectivity in the workplace, there are few studies 
of university leaders from a psycho-social or life history perspective. School leadership research from Harry Wolcott's study of 'The man in the principal's office' (Wolcott 1973) to Sara Lightfoot-Lawerence's work on 'portraiture' (Lightfoot-Lawerence/ Hoffmann Davis 1997) have elevated the subjective element in leadership but there is a true absence of similar work at the level of universities. Where this exists, for example Baldridge's (1971) study of executive decision-making on American campuses, Cohen and March's (1974) study of organisational processes, also in US universities, or Becher's work on 'academic tribes' in the UK (Becher/ Trowler 2001) we fail to uncover fully the subjective interests and motivations of the new executive 'actor' in higher education.

Whilst the Law of 2003 shapes and constrains the 'space of the possible' I suggest we study who these people are as a key to understanding the way that global discourses, national visions, local responses and specific individual subjectivities interact. Danish higher education has become a rich field for the exercise of power and influence. The new 'hero' in Danish university reform is the internationally-oriented, research-strong saviour/ entrepreneur. In no other age has there been space for such personalities. They embrace the reforms but, also, embody them; they often criticise the direction of Government policy but provide remarkably similar policy solutions themselves. From the perspective of Foucault's notion of governmentality, these actors not only utilise the dominant discourse and 'political technologies' of the day, but become integrated with them.

Like Stephen Ball (1994) I find this view - grounded in Foucault's notion of discourse - attractive and persuasive but am not yet ready to dismiss the 'the constraints of the material context' or the role of 'purposive agency' (p. 4) in social life. My way forward has been to take seriously Lakomski's (2005) critique of the construct of leadership; to acknowledge the absence of any clear and accepted connection between theory, claim, and empirical observation. Perhaps if we put aside our apriori fixation on 'leadership as category' we can acknowledge the debt to the 'heroic' ideal in the legislation now shaping universities in Denmark but, instead of legitimising it as material fact, look upon contemporary constellations of actors and steering instruments as the latest, perhaps most sophisticated, attempt to establish a regime of power in a social field that has always been constructed around inequalities.

Whilst earlier regimes rallied around notions of 'democracy' and highlighted those vested interests who threatened this ideal, we now have a more subtle and seductive master: the heroic leader allegedly acting in our best interests but nevertheless causing violence to our purpose, values and identities. It may be convenient to blame leadership', especially the way that this is constructed in law and policy, but Lakomski challenges us to ask the question: 'have we been here before?' Whether as part of a discourse of democracy or one grounded in the confident language of managerialism, the common element in both reform eras has been the way in which powerful groups have been able to manipulate the rhetoric of the times to achieve their own ends. The new systems of governance and management currently being implemented in Danish education may simply be the latest way in which to organise this violence, meaning, necessarily, that we can only critique contemporary efforts to restructure education though a critique of the supposed 'golden age' when academics were 'equal', our so- 
called 'leaders' were 'democratic' and institutions served a 'social purpose'. Things have changed, but not absolutely (Ball 1998).

\section{References}

Baldridge, J. V. (1971): Power and Conflict in the University. New York: John Wiley.

Ball, S. J. (1994): Education Reform: A critical and post-structural approach. Buckingham: Open University Press.

Ball. S. J. (1995): Intellectuals or technicians: The urgent role of theory in educational studies. In: British Journal of Educational Studies, 43 (3): 255-271.

Ball, S. (1998): Big policies / small world: An introduction to international perspectives in education policy. In: Comparative Education, 34 (2): 119-130.

Bass, B. M. (1985): Leadership and performance beyond expectation. New York: Free Press.

Bass, B. M./Avolio, B. J. (eds) (1994): Improving organisational effectiveness through transformational leadership. Thousand Oaks: Sage.

Becher, T./Trowler P. (2001): Academic Tribes and Territories. Buckingham: Open University Press.

Burns, J. M. (1978): Leadership. New York: Harper Torchbooks.

Carney, S. (2006): University governance in Denmark: From democracy to accountability? In: European Educational Research Journal: 221-233.

Cohen, M. D./March, J. G. (1974): Leadership and Ambiguity: The American college president. New York: McGraw-Hill.

Dean, M. (1999): Governmentality: Power and rule in modern society. London: Thousand Oaks.

Ernø-Kjølhede, E./Husted, K./Mønsted, M./Barlebo Wenneberg, S. (2000): Managing University Research in the Triple Helix. Copenhagen: Department of Management, Politics and Philosophy.

Etzkowitz, H. (2002): The Triple Helix of university - industry - government: Implications for policy and evaluation. Stockholm: Institutet för studier av utbildning och forskning.

Green, M. F. (1994): Not for wimps or cowards: Leadership in the post-heroic age. In: Educational Record, 75 (3): 55-60.

Greenleaf, R. (1998): The power of servant-leadership: Essays. In: Spears, L.C. (ed): San Francisco: Berrett-Koehler.

Krejsler, J. (2006): Discursive battles about the meaning of university: The case of Danish university reform and its academics. In: European Educational Research Journal: 211-220.

Lakomski, G. (1999): Against leadership: A concept without a cause. In: Begley, P./Leonard, P. (eds): The Values of Educational Administration. London: Falmer Press: 36-50.

Lakomski, G. (2005): Managing Without Leadership: Towards a theory of organisational functioning. Oxford: Elsevier.

Lightfoot-Lawerence, S./Hoffmann Davis, J. (1997): The Art and Science of Portraiture. San Francisco: Jossey-Bass.

Moos, L. (2006): 'Fra politiske demokratidiskurser mod markedsorienterede effektivitetsdiskurser'. In: Nordisk Pedagogik, 26(3): 322-332, ('From a political democratic discourse to a market-oriented effectivity discourse').

MVTI (Ministry of Science, Technology and Innovation) (2002): Political Agreement on a University Reform, 11 October 2002. Copenhagen: MSTI.

MVTI (Ministry of Science, Technology and Innovation) (2003): University Act: a Bill for Act of universities (The University Act). Copenhagen: MSTI.

Wolcott, H. (1973): The Man in the Principal's Office. Eugene: University of Oregon. 